\title{
ENERGY AND NITROGEN BALANCES AS AFFECTED BY ANIMAL SPECIES AND INTAKE LEVEL UNDER DESERT CONDITIONS
}

\author{
A.R. Askar(1), K.M. Abdel-Rahman(2), H.T. Taie(2), K.Z. Kewan(1), \\ H.S. Badawy(1) and F.F. Fayed(1) \\ (1) Department of Animal and Poultry Nutrition, Desert Research Center, P.O. BOX 11753, \\ Egypt \\ (2) Department of Animal Production, Faculty of Agriculture, Menoufia University, Egypt
}

Received: Sep. 27,2020

Accepted: Oct. 4,2020

\begin{abstract}
Thirty-two adult dry females, age 4-5 yrs.; Balady goats ( $n=16$ and average body weight $31.11 \pm 1.63 \mathrm{~kg}$ ) and Barki sheep ( $n=16$ and average body weight $34.53 \pm 1.56 \mathrm{~kg}$ ) were used to study effects of long-term restricted feeding regime on body weight changes and balance of energy and protein. Animals of each species were allocated to two levels of feed intake; control feeding treatment (CON) where animals were fed a diet at a level of feeding to meet approximately the metabolizable energy for maintenance requirement (MEm), while those on the other dietary treatment was fed almost $50 \%$ of these quantities on a BW basis, termed as the restricted treatment (restricted; RES). Alfalfa hay and concentrate feed mixture (50:50\% as DM basis) were given based on requirement recommendations. The results could be summarized as follows:
\end{abstract}

The ADG was not affected $(P<0.05)$ by animal species (BG vs. $S H)$, however, it was affected $(P<0.01)$ by feed intake level where the RES animal group showed a negative ADG (-65.6 g/d) compared with the CON group that achieved positive ADG (36.4 g/d).

Both of SH and BG had similar negative energy balance (EB) values $(67.0$ vs. $61.4 \mathrm{KJ} /$ $\mathrm{kg}^{0.75} / \mathrm{d}$, for $B \mathrm{BG}$ and $\mathrm{SH}$ respectively).

Nitrogen balance (NB) was greater $(P<0.01)$ for SH $\left(107.64 \mathrm{mg} / \mathrm{kg}^{0.75} / \mathrm{d}\right)$ vs. BG $(89.47$ $\left.\mathrm{mg} / \mathrm{kg}^{0.75} / \mathrm{d}\right)$ and was greater $(P<0.01)$ for animals fed on CON intake $(251.47$ vs. 208.55 $\mathrm{mg} / \mathrm{kg}^{0.75} / \mathrm{d}$, respectively) than those fed on RES intake $\left(-36.18 \mathrm{vs}\right.$. $-29.62 \mathrm{mg} / \mathrm{kg}^{0.75} / \mathrm{d}$, respectively), which gave a negative NB.

It could be concluded that with desert conditions, sheep may have an advantage in a decreasing Metabolizable energy for maintenance $\left(M E_{m}\right)$ requirement and reduction in heat production of a magnitude adequate to maintain body weight. There is a similar rate of using the energy between sheep and goats with moderate or limited nutrition planes.

Key words: Barki sheep, Balady goats, Feed intake level, digestibility, Energy balance, Nitrogen balance

\section{INTRODUCTION}

The drought period is characterized by nutritional deficiency and during which the rate of production of feed is less than its rate of consumption. Drought periods have striking effects which may be summarized as follows: 1 ) reduction in the stock number and the amount and quality of wool production.
2) long term effects on feed production. 3) delays in mating and hence lower production. However, the feed available to grazing animals during drought will consist of varying productions of a) pasture, usually mature and low nutritive value, b) pasture residues, seeds, burrs, c) shrubs such as saltbush, d) tall shrubs and trees. 
A.R. Askar, et al.,

The productivity of the animal population is dependent upon the availability of feed especially at critical times such as growth, pregnancy, and lactation. Metabolizable energy (ME) requirements for maintenance (MEm) can be influenced by several factors, including animal breed (Patra et al. (2009) and Helal et al. 2010) and feed intake level (NRC, 2007; Helal et al., 2011). Ruminants can adapt to restricted feed intake by reducing their basal metabolic rate as an adaptation mechanism for survival under a restricted feeding regime (Asmare et al., 2006; Helal et al., 2011). This is explained by a reduction in energy used by the splanchnic tissues (Asmare et al., 2012), which account for a considerable portion of the fasting metabolic expenditure (Sainz and Bentley, 1997; NRC, 2007). In this regard, previous studies have shown that feed intake level affects nutrients requirements, particularly in desert animals such as black Bedouin goats (Brosh et al., 1986; Silanikove, 1987). Feeding Bedouins goats half of their adlib intake results in a reduction in heat production to a magnitude adequate to maintain body weight (Choshniak et al., 1995). Similar observations were found in Boer and Spanish meat goats, which can reduce MEm in limited nutritional planes, so this may not be unique to particular genotypes, such as the desert goat (Asmare et al., 2006) and Helal et al. (2011).

There are three main goat breeds in Egypt: Balady, Barki, and Zaraibi. Balady goats are the most numerous and are known for being highly fertile and prolific non-seasonal breeders (Helal et al., 2010). Balady goats and Barki sheep have different ability to adapted to the environmental conditions of the desert area, including a prolonged dry season, extreme climate fluctuations, and water scarcity.
The objective of the present experiment was to study the effect of long term severely restricted feed intake on digestion, and energy expenditure and utilization in Balady and Barki sheep.

\section{MATERIALS AND METHODS}

This experiment was carried out, from 19 June 2014 to 5 January 2015 at the Maryout Desert Research Station which belongs to the Desert Research Center, DRC, some $35 \mathrm{~km}$ southwest of Alexandria, $180 \mathrm{~km}$ north of Cairo, Egypt, at latitude $31^{\circ} 13^{\prime} \mathrm{N}$ and longitude $29^{\circ} 58^{\prime}$ E. It is a semi-arid region with low erratic rainfall averaging less than $150 \mathrm{~mm} /$ year mostly in the winter season. Average ambient temperatures were $37^{\circ} \mathrm{C}$ and $13^{\circ} \mathrm{C}$, and relative humidity values were $69 \%$ and $71 \%$ for the summer and winter seasons, respectively.

The experimental procedures were approved by the Animal and Poultry Production Division of DRC committee and as followed by the Veterinary and Animal Care Department.

\section{Animals and Treatments}

Thirty-two adult dry females, age 4-5 yrs.; Balady goats $(n=16$ and average body weight $31.11 \pm 1.63 \mathrm{~kg}$ ), and Barki sheep ( $n=16$ and average body weight $34.53 \pm 1.56 \mathrm{~kg}$ ), were individually housed in $1.0 \times 1.5 \mathrm{~m}$ pens with a sand floor for three months period then moved to metabolic cages to study effects of longterm restricted feeding regime on digestion and energy expenditure (EE) and energy and protein balance. Animals of each species were allocated to two levels of feed intake. Animals on a control feeding treatment (CON) were fed a diet with adequate energy of maintenance or at a level of feeding to meet approximately the metabolizable energy for maintenance requirement (MEm), while those on the other dietary treatment was fed almost $50 \%$ of these 
quantities on a BW basis, termed as the restricted treatment (restricted; RES). Alfalfa hay and concentrate feed mixture (50:50\% as DM basis) were given based on requirement recommendations of Farid et al. (1983) and Helal et al. (2010). The chemical composition of each feed ingredient is presented in Table 1.

\section{Experimental procedures:}

Animals were kept in individual pens for 3 months on the feeding regimes of the control and restricted levels (Table 2). Water was available free choice twice daily, at 08:00 and 14:00 h. Bodyweight was determined bi-weekly before the offer of feeds and water. Directly after the individual feeding period, animals were moved to metabolic crates in three sets of twelve, two animals per treatment and animal species for each set, for collection of feces and urine.

It lasted for a 7-day collection period for each animal after feed intake establishment. Feed and orts were sampled to get a proportional composite sample per animal for 7 days starting 24 $h$ in advance of the excreta collection period. Feces and urine output were daily collected and a ten percent sub-sample of each taken and pooled in individual composite samples for the 7-day collection period. Individual pooled samples for each animal were preserved frozen pending analyses. At the end of the collection period, composite samples of roughage and feces were oven-dried at $55^{\circ} \mathrm{C}$ to constant weight, ground to pass through a $1 \mathrm{~mm}$ screen, and preserved in plastic bottles for later analysis.

Table (1). Chemical composition of alfalfa hay and concentrate supplement.

\begin{tabular}{|l|cc|}
\hline Constituents & Alfalfa hay & $\begin{array}{c}\text { Concentrate feed mixture } \\
\text { (CFM) }\end{array}$ \\
\hline Dry matter, \% & 88.00 & 90.00 \\
Organic matter, \% & 89.00 & 89.31 \\
Crude protein, \% & 12.25 & 13.33 \\
Neutral detergent fiber, \% & 58.63 & 50.21 \\
Gross energy, MJ/Kg DM & 14.72 & 15.99 \\
\hline
\end{tabular}

Table (2): Experimental feeding regimes

\begin{tabular}{|c|c|c|c|c|c|c|c|c|}
\hline \multirow{3}{*}{ Items } & \multirow{2}{*}{\multicolumn{2}{|c|}{ Species }} & \multirow{2}{*}{\multicolumn{2}{|c|}{ Feeding level }} & \multicolumn{4}{|c|}{ Specie $x$ Feeding level } \\
\hline & & & & & \multicolumn{2}{|c|}{ CON } & \multicolumn{2}{|c|}{ RES } \\
\hline & BG & SH & CON & RES & BG & SH & BG & SH \\
\hline $\begin{array}{l}\text { Animal No. } \\
\mathrm{Fl}^{*}(\mathrm{~g} \mathrm{DM} / \mathrm{head} / \mathrm{d}) \text { : }\end{array}$ & 16 & 16 & 16 & 16 & 8 & 8 & 8 & 8 \\
\hline CFM & 337 & 334 & 446 & 225 & 460 & 431 & 214 & 236 \\
\hline Hay & 337 & 334 & 446 & 225 & 460 & 431 & 214 & 236 \\
\hline
\end{tabular}

\footnotetext{
*Feed intake
} 
A.R. Askar, et al.,

\subsection{Energy expenditure (EE):}

All animals were fitted with a face mask of an open-circuit respiratory system for $\mathrm{O}_{2}$ consumption measurements. Heart rate (HR) was simultaneously determined at the same time to get the individual EE/HR ratio for each animal. Measurements of $\mathrm{O}_{2}$ consumption were made twice daily in the morning and afternoon as described by Landau et al. (2006). The concentration of $\mathrm{O}_{2}$ was analyzed using a fuel cell FC-1B 02 analyzer (Sable Systems, Las Vegas, NV) and EE was estimated assuming a constant thermal equivalent of $20.47 \mathrm{~kJ}$ per liter $\mathrm{O}_{2}$ (Nicol and Young, 1990).

\subsection{Heart rate}

Heart rate was measured on animals fitted with Vermed Performance Plus ECG electrodes (Bellows Falls, VT) attached to the chest just behind and slightly below the left elbow and at the middle right side of the back. Electrodes were secured to the skin with a $5-\mathrm{cm}$ wide elastic bandage (Henry Schein, Melville, NY) and animal tag cement (Ruscoe, Akron, OH). Electrodes were connected by ECG snap leads (Bioconnect, San Diego, CA) to T61 coded transmitters (Polar, Lake Success, NY). Human S610 HR (Polar Electro Oy, Kempele, Finland) monitors with infrared connections to the transmitters were used to collect HR data at a 1-min interval. Heart rate data were analyzed using Polar Precision Performance SW software provided by Polar Electro Oy. Heart rate was measured for each animal on elevated cages for at least 48hrs. The diurnal HR and EE were determined from the EE/HR ratio for each animal.

\section{Analytical procedures}

Dry matter (DM) content of feeds, orts, and feces was determined by drying at $105^{\circ} \mathrm{C}$ for $24 \mathrm{~h}$, and the organic matter
(OM) was determined by ashing at $550^{\circ} \mathrm{C}$ in a muffle furnace for $6 \mathrm{~h}$. The crude protein (CP) was measured by the Kjeldahl method as described by AOAC (2005). The neutral detergent fiber (NDF) content was determined according to Mertens (2002), using the filter bag technique (ANKOM Technology Corp., Fairport, NY, USA). Gross energy (GE) of feed, orts, and feces were measured by bomb calorimeter (IKA, model C 5000, Staufen, Germany), using benzoic acid as standard. Digestible energy (DE\%) was determined according to McDonald et al. (1981) as follows:

DE, $\%=$

$\underline{(\text { Gross energy of total feed intake - Gross energy of feces) } \times 100}$ Gross energy of total feed intake

Metabolizable energy (ME) intake was estimated as $82 \%$ of digestible energy (DE) intake (NRC, 1981).

\section{Statistical Analysis}

Data were analyzed by the GLM procedure of the SAS statistical package (SAS, 2000) with a model consisting of animal species, intake level, and animal species $x$ intake level. Means were presented in tables for animal species $X$ intake level regardless of the significance of the interaction effect. The least significant difference (LSD) was used for comparing means. Differences among means with $\mathrm{P}<0.05$ were accepted as statistically significant differences and those with $0.05<P<0.1$ were accepted as representing tendencies to differences.

\section{RESULTS AND DISCUSSION}

\section{Body weight change:}

Balady goats; BG vs. Barki sheep; SH allocated in the experimental groups started with similar $(P<0.05)$ initial BW and keep FBW similar $(P<0.05)$ among groups after 90 days of feeding animals on the experimental rations (Table 3). The ADG was not affected $(P<0.05)$ by animal species (BG vs. SH) being $\mathbf{4 5 . 1}$ and $\mathbf{5 6 . 8}$ g/d, respectively. However, ADG was 


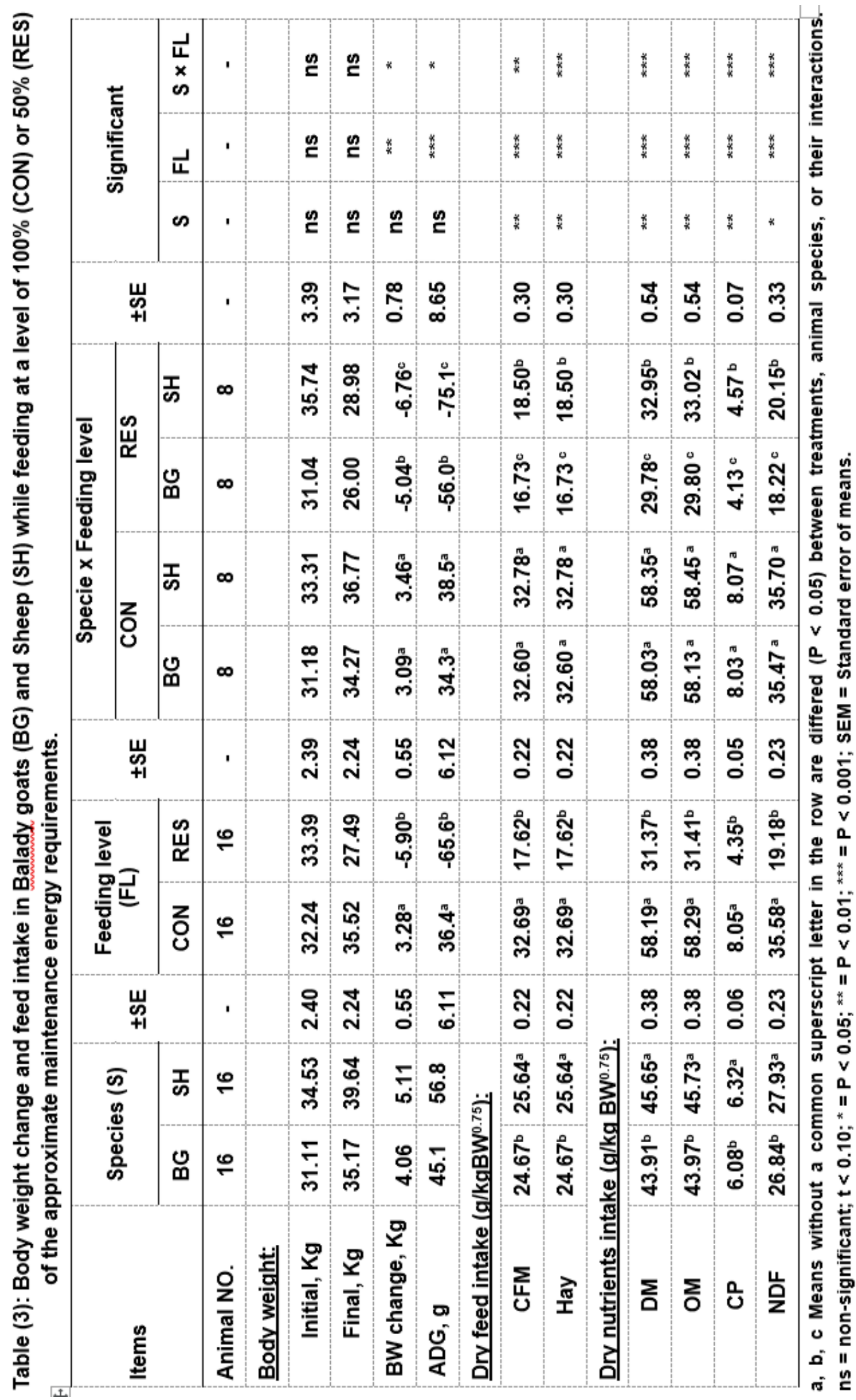


A.R. Askar, et al.,

affected $(P<0.01)$ by feed intake level where the RES animal group showed a negative ADG $(-65.6 \mathrm{~g} / \mathrm{d})$ compared with the CON group that achieved positive ADG (36.4 g/d). Concerning the interaction between animal Specie and feed intake level, data cleared that, ADG was not significantly different between BG (34.3 g/d) and SH (38.5 g/d) under the CON feeding level, however, BG showed less negative ADG $(-56.0 \mathrm{~g} / \mathrm{d})$ compared with SH $(-75.1 \mathrm{~g} / \mathrm{d})$ under RES feeding level. In this regard, Choshniak et al. (1995) reported that feeding Bedouin goats on half of their ad-lib intake results in a reduction in heat production to a magnitude adequate to maintain body weight. On contrary, Asmare et al. (2012) found that the changes in BW were lowest $(P<0.05)$ among Boer, Spanish goats, and Rambouillet sheep consumed grass hay ad-lib or restricted intakes. Therefore, Askar (2016) reported that BW was negatively affected by long-term restricted feeding when BG and SG were fed on $50 \%$ of their control under moderate cold conditions.

\section{Nutrients intake}

The results in Table (3) indicated that dry matter (DM), organic matter (OM), crude protein (TCP) and neutral detergent fiber (NDF) intakes $\left(g^{\prime} / \mathbf{k g}^{0.75}\right)$ were higher $(P<0.01)$ for SH vs. BG. The mean values were 45.65 vs. 43.91 for DM and 45.73 vs. 43.97 for OM and 6.32 vs. 6.08 for CP and 27.93 vs. 26.84 for NDF in SH vs. BG, respectively. These finding may be due to increased maintenance requirements from the energy of sheep than goats because sheep are less able to reduce energy expenditure (EE) than goats which may have involved differences in extra-splanchnic tissue metabolism. These results are in agreement with those of Asmare et al. (2012). Concerning the effect of feeding level treatment, DM, $\mathrm{OM}, \mathrm{CP}$, and NDF intakes were greater $(P<0.01)$ for control vs. restricted intake level (58.19 vs. 31.37, 58.29 vs. 31.41, 8.05 vs. 4.35 , and 35.58 vs. 19.18, respectively). Also, a significant interaction was detected between animal species and intake levels (Table 3). Under control intake level (CON), BG and SH had similar values of DM, OM, CP, and NDF intakes as $\mathrm{g} / \mathrm{kg}^{0.75}$. However, at a restricted intake level, $\mathrm{SH}$ had a greater $(P<0.01)$ of DM, OM, CP, and NDF intakes than BG. Similar feed intake was previously reported between goats and sheep when they fed a high-quality forage (alfalfa hay, 64.0 and $68.7 \mathrm{~g}$ dry matter/Kg ${ }^{0.75}$, El-Meccawi et al., 2008) or a low-quality forage (wheat straw, 42.6 and $43.4 \mathrm{~g}$ dry matter/ $\mathrm{Kg}^{0.75}$, El-Meccawi et al., 2009).

\section{Nutrients Digestibility.}

Sheep showed greater $(P<0.01)$ digestibility for DM, OM, CP, and NDF compared to BG (Table 4). The mean values were 56.03 vs. $50.83 \%$ for DM and 62.80 vs. $58.33 \%$ for $O M$ and 61.72 vs. $58.30 \%$ for CP and 57.80 vs. $51.67 \%$ for NDF in Sheep vs. BG, respectively. In this regard, it should be mentioned that Barki sheep are well adapted to the desert condition of Egypt and can survive on very poor quality forage. Similar results were observed by Askar (2015) who evaluated the effects of long-term nutrient restriction on digestion by dry adult Barki ewes and desert goats and reported that, a greater $(P<0.01)$ of $D M$ digestibility for sheep vs. goats at restricted feed intake level (60.8 vs. $50.9 \%$, respectively).

Regarding the feed intake level effect, animals on control intake level had higher $(P<0.01)$ values of $D M, O M, C P$, and NDF digestibility than that in animals fed on restricted intake level. Conversely, some experiments carried out in underfed ruminants, which have shown either no variation in digestibility with the intake (Grimaud and Doreau, 1995) or 


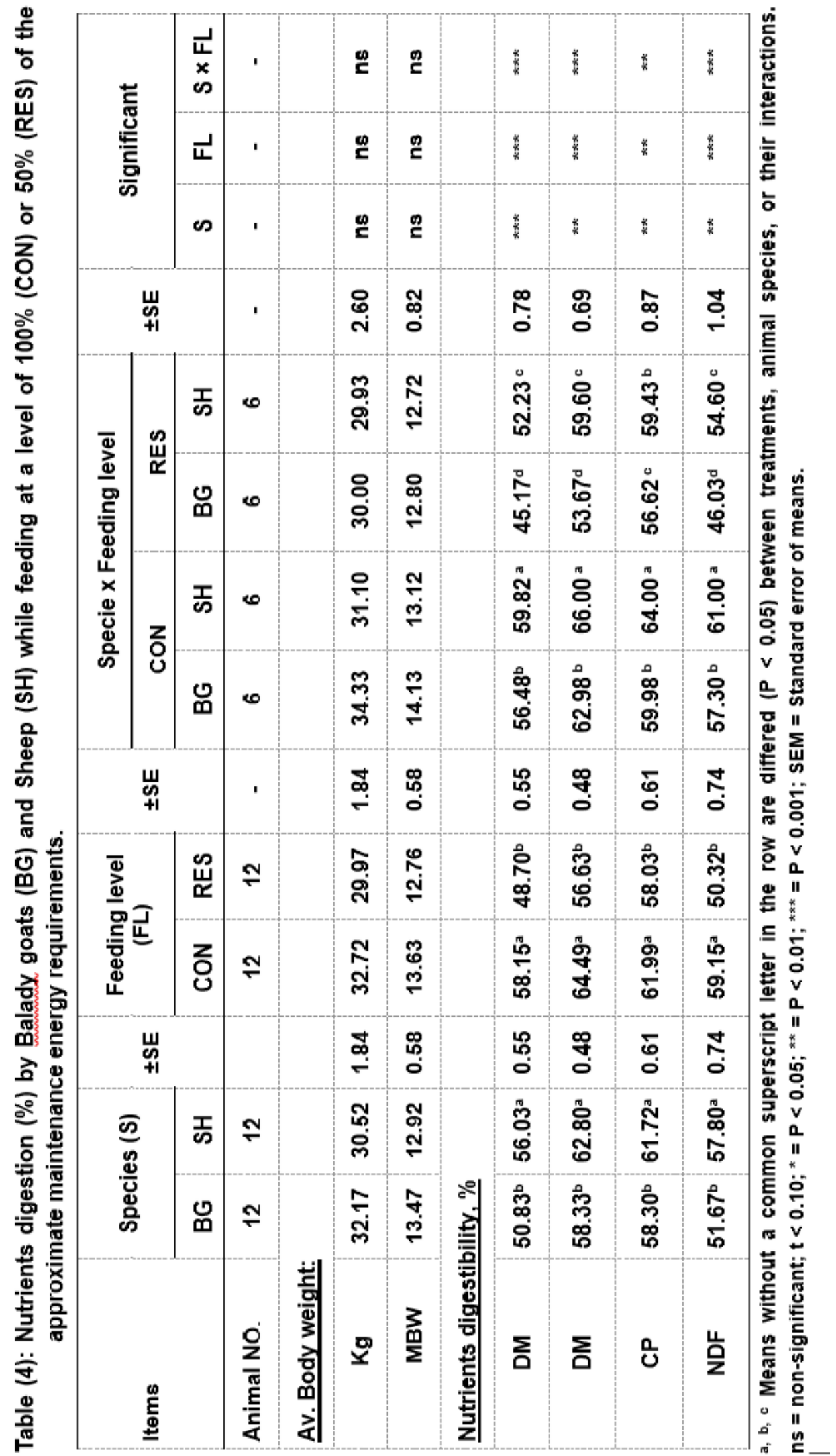


a decrease for Zebu (Bos indicus) and Taurus (Bos taurus) cattle (Grimaud et al., 1998). Restriction of feed intake often enhanced $O M$ digestibility owing to higher retention time in the rumen (Galyean and Owens, 1991).

At the same trend, a significant interaction was detected between animal species and intake levels regarding the digestibility. Sheep had higher $(P<0.01)$ values of $\mathrm{DM}, \mathrm{OM}, \mathrm{CP}$, and NDF digestibility than BG under both the CON and RES intake levels. Factors responsible for the reduction in goat digestibility are unclear but Askar (2015) reported a significant reduction in digestibility of Balady and Shami goats fed the same restricted diet under similar moderate cold conditions. He also suggested that goats are much sensitive to the low ambient temperature, particularly when they were given a low feed intake level below maintenance, and that may be due to their coat type. However, this reduction in digestibility might be also due to lower fermented energy available for rumen microflora and/or to a greater endogenous nitrogen excretion (\% of intake) for restricted vs. control feed intake level. Besides, wool is very effective insulation against cold and hot, however, many investigators have reported the influence of fleece length and level of feed intake on lowering the critical temperature in sheep as mentioned by the NRC (1985). However, a similar digestibility for both animal species was reported when they were fed ad lib alfalfa hay (63.1 and $63.9 \%$, ElMeccawi et al., 2008) and (66.7 and 65.9\%, Askar et al., 2016) as a sole diet. On the other hand, the effect of restricted feed intake on digestibility depends on several factors, such as water consumption and diet quality (Ahmed and Ammar, 2001). The latter authors reported that desert goats subjected to feed restriction display similar or numerically lower nutrients digestibility than those subjected to ad-lib feeding when fed alfalfa hay.

\section{Energy utilization:}

Data of gross energy (GE), digestible energy (DE), and metabolizable energy (ME) of Balady goats and sheep are shown in Table (5). It could be noticed that sheep had higher $(P<0.01)$ intake values of both GE, DE, and ME than Balady goats when it was expressed as $\mathrm{kJ} / \mathrm{kg}^{0.75} /$ day. The mean values were 787 vs. 757 for GE and 500 vs. 445 for DE and 410 vs. $365 \mathrm{~kJ} / \mathrm{kg}^{0.75} / \mathrm{day}$ for ME in SH vs. BG, respectively. Digestible energy (\%) was observed following the same trend of the DM and OM digestibility (Table 6). Sheep had a higher $(P<0.01)$ value of $D E$ $\%$ than BG being mean values were 62.64 vs. $\mathbf{5 7 . 0 2} \%$ for SH vs. BG, respectively. These results were in agreement with those of Askar (2016) under moderate cold condition. The increase of ME by SH with hot conditions might be due to its capability of reducing the Metabolizable energy for maintenance $\left(\mathrm{ME}_{\mathrm{m}}\right)$ requirement and reduction in heat production of a magnitude adequate to maintain body weight. Also, Wool is very effective insulation against cold and hot. The influence of fleece length and level of feed intake on lowering the critical temperature in sheep was mentioned by the NRC (1985).

Concerning the effect of feed intake level, animals fed on CON intake level had higher $(P<0.05)$ values of $G E, D E, M E$ intakes and $D E \%$ than those in RES intake level (1003 vs. 541 kJ/kg ${ }^{0.75} /$ day for GE, 645 vs. $300 \mathrm{~kJ} / \mathrm{kg}^{0.75} /$ day for DE, 529 vs. $246 \mathrm{~kJ} / \mathrm{kg}^{0.75} / \mathrm{day}$ for ME and 64.34 vs. $55.14 \%$ for DE\%, respectively). Under the CON level, there are no significant differences between SH and BG for GE, $D E$, and $M E$ intakes $\left(\mathrm{kJ}^{\mathrm{k}} \mathrm{kg}^{0.75} /\right.$ day). A similar trend was observed for DE \% under the CON intake level. However, under the RES intake level, sheep had higher $(P<0.01)$ values of $G E, D E$, and ME 


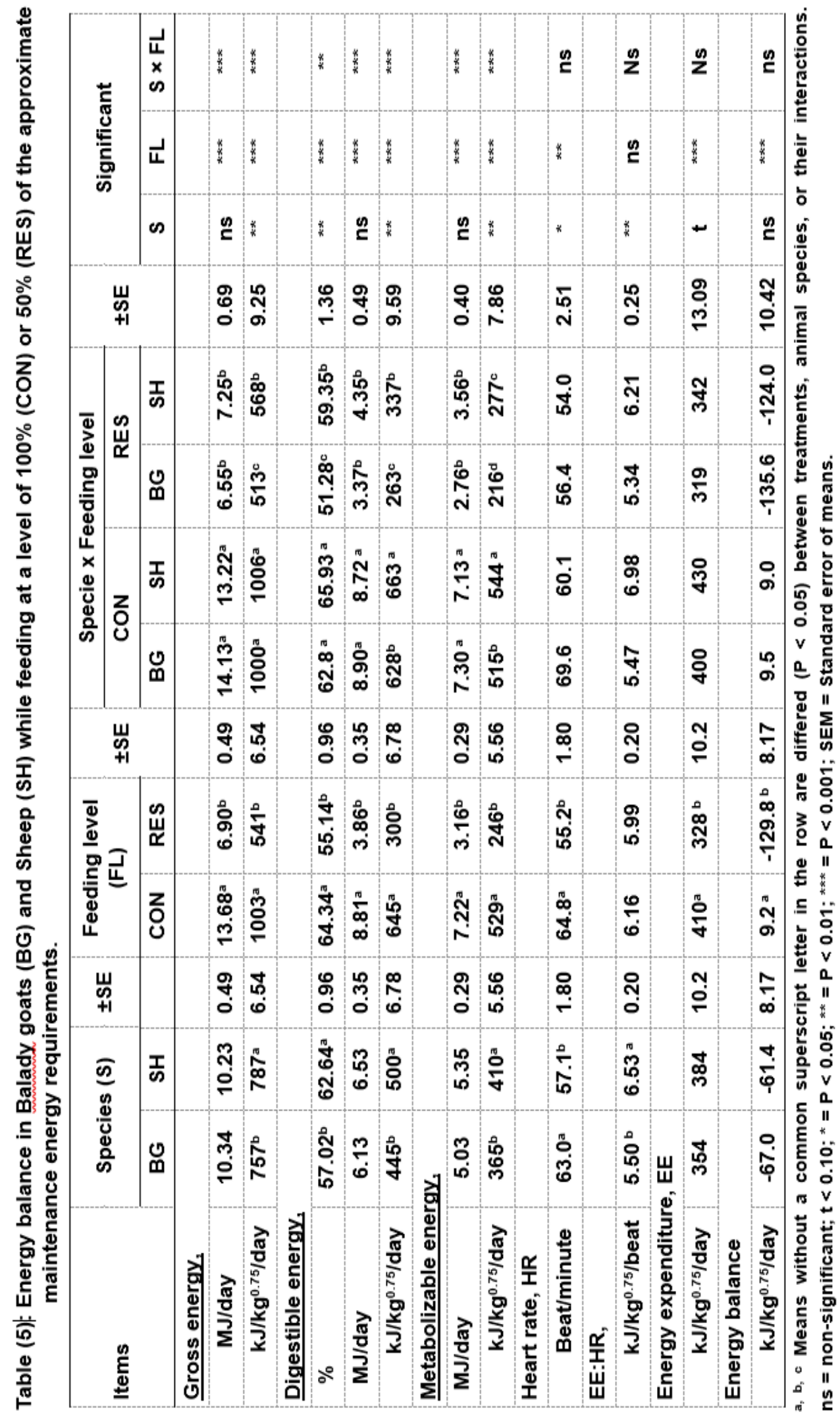


intakes than BG. Also, digestible energy (\%) was following the same trend of energy intake. These results were in agreement with those reported by Farid (1997). In this respect, Helal et al. (2011) concluded that the trend of change in heat production in response to feeding restriction and re-alimentation was varied among different goat genotypes that consequently affecting the MEm.

\section{Heart rate (HR): energy expenditure (EE) ratio:}

The heart rate was higher $(P<0.01)$ for BG vs. SH when it was expressed as beats/min Table (5). Mean values were 63.00 vs. 57.10 for BG vs. SH, respectively. However, energy expenditure to heart rate ratio (EEI HR ratio) was higher $(P<0.01)$ for $\mathrm{SH}$ than $B G$ when it was expressed as $\mathrm{kJ}^{\mathrm{kg}} \mathrm{kg}^{0.75} / \mathrm{beat}$, mean values were 6.53 vs. 5.50 for SH vs. BG, respectively. The differences between sheep and goats in EE/HR ratio are not clear but the delivery of oxygen by the heart probably varies among ruminant species (Puchala et al., 2007). Results are in agreement with those previously reported by Beker et al. (2010) who reported a greater EE/HR ratio for Rambouillet sheep vs. Spanish and Angora goats (6.47 vs. 6.02 and 5.64 $\mathrm{kJ} / \mathrm{kg}^{0.75} /$ beat, respectively). Concerning the effect of feed intake level, it could be observed that HR was significantly $(P<0.01)$ higher for animals fed control intake level vs. restricted, mean values were 64.8 vs. 55.20 beats/minute. On the other hand, a similar EE/HR ratio was observed for animals under both control and restricted intake levels. The reduction in HR was mainly due to the lower in the feed intake by animals fed on RES intake vs. CON intake and consequently reduced the heat increment requested for feeding (Asmare et al., 2006; El-Meccawi et al., 2008; Asmare et al., 2012). In this regard, Brosh et al. (1986) suggested that the type of diet affects the heat production and that the small desert ruminants can reduce their metabolic rate when consuming a lowquality diet as a mechanism for adaptation. Also, low nutritional planes reduce heat production or energy expenditure (EE) by cattle and sheep (Freetly et al., $2002 \&$ 2003). There was no significant interaction between animal species and feed intake levels, revealed a similar HR and EE: HR ratio values between SH and BG when they fed on either CON or RES intake. In a similar experimental design, a similar EE/HR ratio was noted between control and restricted feed intake levels in Angora, Boer, and Spanish goats (Helal et al., 2011) and Balady and Shami goats (Askar, 2015). Moreover, Arieli et al. (2002) reported a similar EE/HR ratio in Assaf sheep fed different diets varying in forage/concentrate ratio.

\section{Energy expenditure and balance:}

Data in Table (5) showed that sheep had an insignificant increase in energy expenditure (EE) compared with BG. This result was in agreement with Asmare et al. (2012) who indicated that with limited planes of nutrition, sheep were less able to reduce EE than goats, which may have involved differences in extra-splanchnic tissue metabolism. On the other hand, both SH and BG had similar energy balance (EB) values which reflected the difference between the MEI and EE. This indicated a similar rate of using the energy between sheep and goats with moderate or limited nutrition planes. A similar EB was reported for sheep and goats when they fed either at high (EIMeccawi et al., 2008) or at low (ElMeccawi et al., 2009) feed intake level that was associated with receiving high or low-quality diet, respectively. TovarLuna et al. (2007) reported that moderate feed intake restriction impacted EE and MEm by mature meat goats largely via 
decreasing $E E$ that is responsive to nutrient intake rather than EE of basal metabolism when fasting.

\section{Nitrogen balance:}

Data on nitrogen intake, excretion, and balance are presented in Table (6). Nitrogen intake (NI), expressed as $\mathrm{mg} / \mathrm{kg}^{0.75} /$ day was higher $(\mathrm{P}<0.01)$ for $\mathrm{SH}$ than that in BG. A similar trend was observed under RES intake, however, there are no significant differences for $\mathrm{NI}$ between two Species under CON intake. While animals fed on CON intake had higher $(P<0.01)$ value of $\mathrm{NI}$ than those fed on RES intake. Concerning the nitrogen excretion $\left(\mathrm{mg} / \mathrm{kg}^{0.75} / \mathrm{d}\right)$, represented in fecal nitrogen (FN) and urinary nitrogen (UN), the present data, indicated that SH had a higher $(P<0.01)$ value of UN $(523.1)$ than BG (482.9), but, there are no significant differences between two Species for FN (380.7 vs. 400.1, respectively) and total nitrogen excretion (903.9 vs. $\left.883.0 \mathrm{mg} / \mathrm{kg}^{0.75} / \mathrm{d}\right)$. Also, regardless of Species, animals under the CON intake level had higher $(P<0.01)$ values of $\mathrm{FN}\left(489.9 \mathrm{mg} / \mathrm{kg}^{0.75} / \mathrm{d}\right)$ and UN $\left(569.2 \mathrm{mg} / \mathrm{kg}^{0.75} / \mathrm{d}\right)$ than that in animals under the RES intake level (290.9 and $436.8 \mathrm{mg} / \mathrm{kg}^{0.75} / \mathrm{d}$, respectively). At the same trend, $F N$ was greater $(P<0.01)$ for BG $\left(514.4 \mathrm{mg} / \mathrm{kg}^{0.75} / \mathrm{d}\right)$ as compared to $\mathrm{SH}$ (465.4 $\left.\mathrm{mg} / \mathrm{kg}^{0.75} / \mathrm{d}\right)$ under CON treatment, while it was similar for the two species under RES intake treatment (285.9 vs. $\left.296.0 \mathrm{mg} / \mathrm{kg}^{0.75} / \mathrm{d}\right)$. However, the UN was greater $(P<0.01)$ for SH $\left(\mathbf{4} 70.2 \mathrm{mg} / \mathbf{k g}^{0.75} / \mathrm{d}\right)$ as compared to $B G\left(403.4 \mathrm{mg} / \mathrm{kg}^{0.75} / \mathrm{d}\right)$ under RES treatment, while it was similar for the two species under CON intake treatment $\left(576.1\right.$ vs. $562.4 \mathrm{mg} / \mathrm{kg}^{0.75} / \mathrm{d}$, respectively.

Nitrogen balance (NB) was greater $(P<0.01)$ for SH $\left(107.6 \mathrm{mg} / \mathrm{kg}^{0.75} / \mathrm{d}\right)$ vs. BG $\left(89.47 \mathrm{mg} / \mathrm{kg}^{0.75} / \mathrm{d}\right)$ and was greater $(P<0.01)$ for animals fed on CON intake
( 251.5 vs. $208.6 \mathrm{mg} / \mathrm{kg}^{0.75} / \mathrm{d}$, respectively) than those fed on RES intake (-36.18 vs. $29.60 \mathrm{mg} / \mathrm{kg}^{0.75} / \mathrm{d}$, respectively), which gave a negative NB. For respect of species and its interaction with feed intake level, SH under the CON level had a higher $(P<0.01)$ value of NB than that in $B G$, and it was a positive balance for two species. However, under the RES level, BG had a higher $(P<0.01)$ value of NB than that in $\mathrm{SH}$, and it was a negative balance for two species. In agreement, Hassan and Abdel-Aziz (1979) found that Barki sheep had a negative NB and could not maintain BW when they consumed Atriplex nummularia alone or supplemented with $50 \mathrm{~g}$ barley grain per day. In this respect, Ahmed and Ammar (2001) concluded that subjecting animals to water or feed restriction will have a more deleterious effect on nitrogen balance when using low than high-quality forage. Similar results were observed by Singh et al. (2008) who found that balance of $\mathrm{N}$ as $\mathrm{g} / \mathrm{d}$ or as \% of absorbed $N$ was significantly $(P<0.01)$ different among four groups $(95,80,60$, and $40 \%$ of the voluntary dry matter intake), being the lowest in group 4. Animals of groups 1,2 , and 3 were in positive nitrogen balance, however, animals of group 4 were in negative $\mathrm{N}$ balance.

\section{CONCLUSION}

Under the desert conditions which are characterized by a lack of food, attention must be by intake of energy, given its importance to animals, then by intake of nitrogen especially sheep and goats.

It could be concluded that Barki sheep are well adapted to the desert condition of Egypt and can survive on very poor quality forage. With hot conditions, sheep may have an advantage in a decreased Metabolizable energy for maintenance $\left(\mathrm{ME}_{\mathrm{m}}\right)$ requirement and reduction in heat production of a 


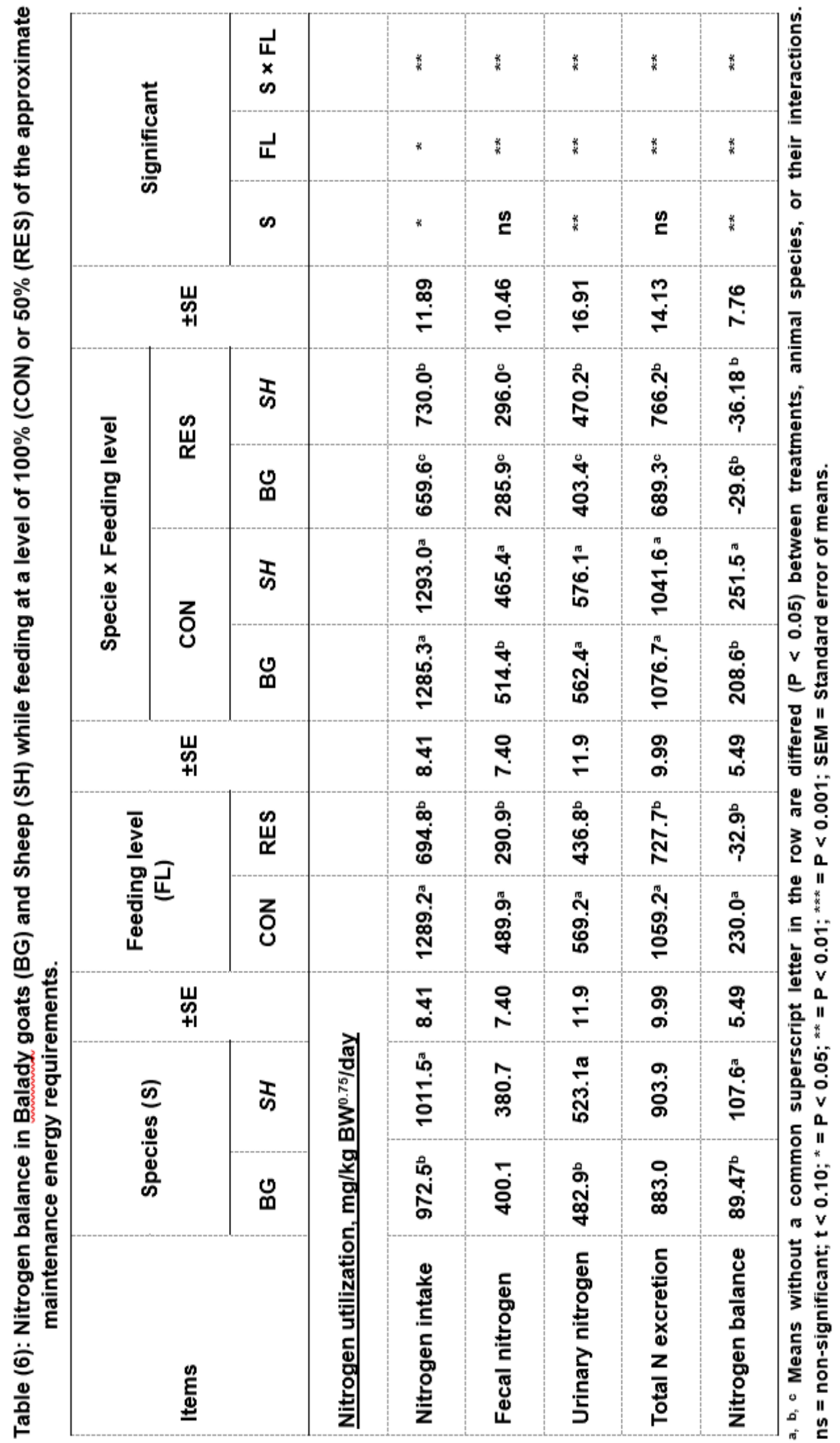


magnitude adequate to maintain body weight. There is a similar rate of using the energy between sheep and goats with moderate or limited nutrition planes.

\section{REFERENCES}

Ahmed, Muna, A.A., I. El Shafei Ammar (2001). Effects of water and feed restriction on body weight change and nitrogen balance in desert goats fed high and low quality forages. Small Ruminant Research, 41: 19-27

AOAC, (2005). Official Methods of Analysis of AOAC International, 18th ed. Association of Official Analytical Chemists, Gaithersburg, MD, USA.

Areili, A., A. Kalouti, Y. Aharoni, and A. Brosh (2002). Assessment of energy expenditure by daily heart rate measurement-validation with energy accretion in sheep. Livest. Prod. Sci., 78: 99-105.

Askar, A,R, (2015). Effects of Feed Intake Level on Digestion and Energy Utilization in Desert Sheep and Goats. J. Am. Sci., 11(5): 88-96.

Askar, A. R. (2016). Effects of long-term restricted feeding on digestion and energy utilization in Balady vs. Shami goats. Livestock Science 185 (2016) 61-67.

Askar, A.R., M.S. Nassar, H.S. Badawy, E.Y. Eid, J.A. Guada, M.F.A. Farid. (2016). Recovered energy and efficiency of digestion in sheep and goats fed Atriplex nummularia compared to alfalfa hay Livestock Science 194: 1-6

Asmare, A., Puchala, R., Merkel, R.C., Sahlu, T., Goetsch, A.L., (2006). Changes in energy expenditure by meat goats with varying levels of feed intake near maintenance and below. J. Appl. Anim. Res. 29, 81-89.

Asmare, A., Puchala, R., Tesfai, K., Detweiler, G.D., Dawson, L.J., Askar, A.R., Sahlu, T., Wang, Z., Goetsch,
A.L., (2012). Effects of small ruminant type and level of intake on metabolism. Small Rumin. Res. 102, 186-190.

Beker, A., T.A. Gipson, R. Puchola, A.R. Asker, K. Tesfai, G.D. Detweiler, A. Asmare and A.L. Goetsch (2010). Energy expenditure and activity of different types of small ruminants grazing varying pasture in summer. $J$. Appl. Anim. Res., 37, 1-14.

Brosh, A., A. Shkolnik and I. Choshniak (1986). Metabolic effects of infrequent drinking and low-quality feed on bedouin goats. Ecology, 67(4): 10861090.

Choshniak, I., Ben-Kohav, N., Taylor, C.R., Robertshaw, D., Barnes, R.J., Dobson, A., Belkinb, V., Shkolnik, A., (1995). Metabolic adaptations for desert survival in the Bedouin goat. Am. J. Physiol. Regul. Integr. Comp. Physiol. 268, R1101-R1110.

El-Meccawi, S. M. Kam, A. Brosh, A.A. Degen (2008). Heat production and energy balance of sheep and goats fed sole diets of Acacia saligna and Medicago sativa. Small Rumin. Res. 75: 199-203

El-Meccawi, S., M. Kam, A. Brosh, A.A. Degen (2009). Energy intake, heat production and energy and nitrogen balances of sheep and goats fed wheat straw as a sole diet. Livest. Sci., 125: 88-91.

Farid M.F.A. (1997). Food intake, diet selection and adaptation to protein deficiency in desert sheep. In: Lindberg J.E. (ed.), Gonda H.L. (ed.), Ledin I. (ed.), Recent advances in small ruminant nutrition. Zaragoza: CIHEAM, Options Méditerranéennes: Série A. Séminaires Méditerranéens; n. 34. pp. 173-183.

Farid, M.F.A., M.M. El-Shennawy, A.Z. Mehrez and A.M.M. Salem (1983). Protein requirements for maintenance 
of Barki desert sheep. World Review of Animal Production, vol. XIX, No. 3, July-September, 31-36.

Freetly, H.C., Nienaber, J.A., BrownBrandl, T.M., (2002). Relationship between aging and nutritionally controlled growth rate on heat production of ewe lambs. J. Anim. Sci. 80, 2759-2763.

Freetly, H.C., Nienaber, J.A., BrownBrandl, T.M., (2003). Relationship between aging and nutritionally controlled growth rate on heat production of heifers. J. Anim. Sci. 81, 1847-1852.

Galyean, M.L., Owens, F.N., (1991). Effects of diet composition and level of feed intake on site and extent of digestion in ruminants. In: Tsuda, T., sasaki, Y., Kawashima, R. (Eds.), Physiological Aspect of Digestion and Metabolism in Ruminants. Acad. Press, San Diego, CA, pp. 483-514.

Grimaud, P., Doreau, M., (1995). Effect of extended underfeeding on digestion and nitrogen balance in non-lactating cows. J. Anim. Sci. 73, 211-219.

Grimaud, P., Richard, D., Kanwe, A., Durier, C., Doreau, M., (1998). Effect of undernutrition and refeeding on digestion in Bos Taurus and Bos indicus in a tropical environment. Anim. Sci. 67, 49-58.

Hassan, N.I., Abdel-Aziz, H.M. (1979). Effect of barley supplementation on the nutritive value of saltbush (Atreplix nummularia). World Rev. Anim. Prod., 15, 47-55.

Helal A., K.M. Youssef, H.M. El-Shaer, T.A. Gipson, A.L. Goetsch, A.R. Askar (2010). Effects of acclimatization on energy expenditure by different goat genotypes. Livest. Sci. 127: 67-75.

Helal, A., Puchala, R., Detweiler, G.D., Gipson, T.A., Sahlu, T., Goetsch, A.L., (2011). Effects of restricted feed intake on energy expenditure by different goat breeds. J. Anim. Sci. 89, 41754187.

Landau, S., Barkai, D., Dvash, L., Brosh, A., (2006). Energy expenditure in Awassi sheep grazing wheat stubble in the northern Negev Desert of Israel. Small Rumin. Res. 105, 265-271.

McDonald, P.; R.A. Edwards and J. F. D. Greenholgh (1981). Animal Nutrition ( $3^{\text {rd }}$ edition). Longman House, Burnt Mill, England. pp479.

Mertens, D.R., (2002). Gravimetric determination of amylase-treated neutral detergent fibre in feeds with refluxing beakers or crucibles: collaborative study. J. AOAC Int. 85, 1217-1240.

Nicol, A., Young, B.A., (1990). Short-term thermal and metabolic responses of sheep to ruminal cooling: effects of level of cooling and physiological state. Can. J. Anim. Sci. 70, 833-842.

NRC (1981). National Research Council. Nutrient Requirements of Goats: Angora, Dairy and Meat Goats in Temperate and Tropical Countries. NO. 15. National Academy Press. Washington, DC, USA.

NRC (1985). Nutrient Requirements of Sheep. Sixth revised edition, National Academy Press, Washington, DC.

NRC (2007). Nutrient Requirements of Small Ruminants. Sheep, Goats, Cervids and New World Camelids. National Academy Press, Washington, DC.

Patra, A.K., R. Puchala, G. Animut, T.A. Gipson, T. Sahlu, A.L. Goetsch (2009). Effects of acclimatization on energy expenditure by meat goats. Small Ruminant Research 81: 42-54.

Puchala, R., I. Tovar-Luna, A.L. Goetsch, T. Sahlu, G.E. Carstens, H.C. Freetly (2007). The relationship between heart rate and energy expenditure in Alpine, Angora, Boer and Spanish goat wethers consuming different quality 
diets at level of intake near maintenance or fasting. Small Ruminant Research 70 (2007) 183-193.

Sainz, R.D., Bentley, B.E., (1997). Visceral organ mass and cellularity in growthrestricted and refed beef steers. J. Anim. Sci. 75, 1229-1236.

SAS, (2000). Statistical Analysis Systems Institute Inc., Release 8.1, Cary, NC., USA.

Silanikove, N., (1987). Effect of imposed reduction in energy intake on resting and fasting heart production in the black Bedouin goat. Nutr. Rep. Int. 35, 725-731.
Singh, P., A.K. Verma, D.S. Sahu, U.R. Mehra (2008). Utilization of nutrients as influenced by different restriction levels of feed intake under subtropical conditions in crossbred calves. Livestock Science 117 (2008) 308-314 4

Tovar-Luna, I., A.L. Goetsch, R. Puchala, T. Sahlu, G.E. Carstens, H.C. Freetly, Z.B. Johnson (2007). Effects of moderate feed restriction on energy expenditure by 2-year-old crossbred Boer goats. Small Ruminant Research 72: 25-32. 
ميزان الطاقة والنيتروجين المتأثر بنوع الحيوان ومستوى الغذاء المأكول تحت الظروف الصحراوية

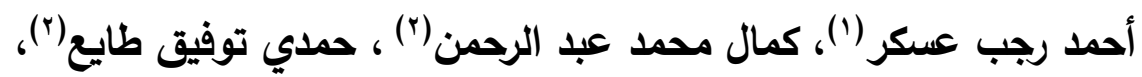

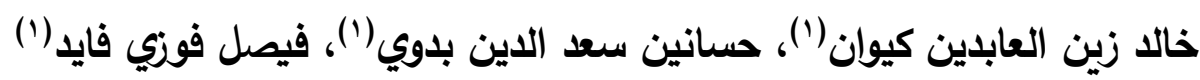

(1) قسم تغذية الحيوان والدواجن، مركز بحوث الصحراء

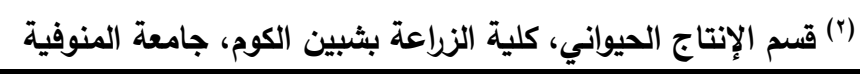

الملخص العربي

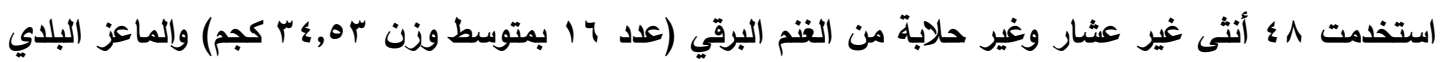

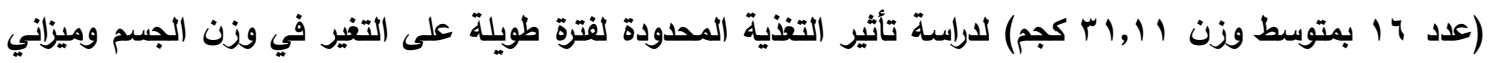
الطاقة والبروتين. قسمت الحيوانات داخل كل نوع الى مجموعتين (^ حيوانات/ مجموعة)، غذيت المجموعة الاولي داخل

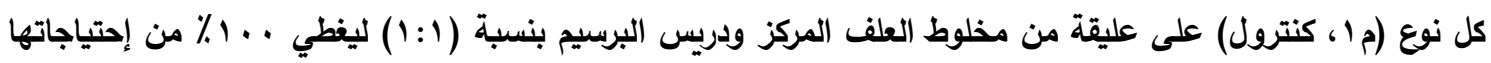

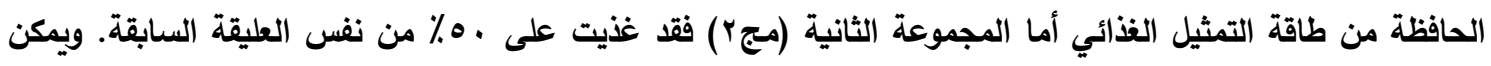

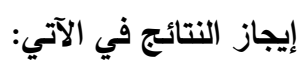

- لم يتأثر معدل تغير وزن الجسم معنويا (P

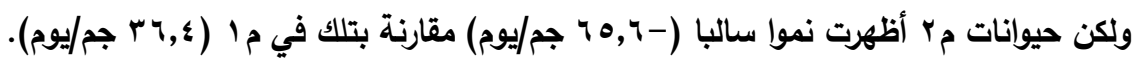

- أظهر نوعي الحيوانات تثابها غير معنوي (P>

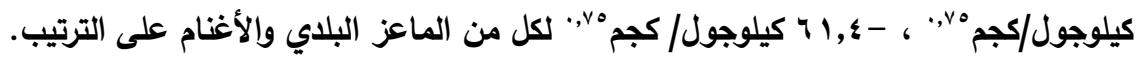

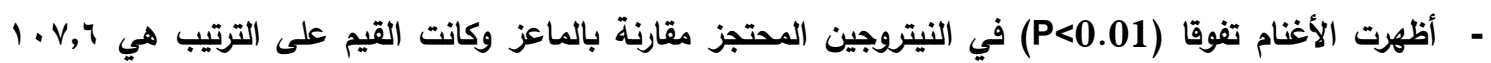

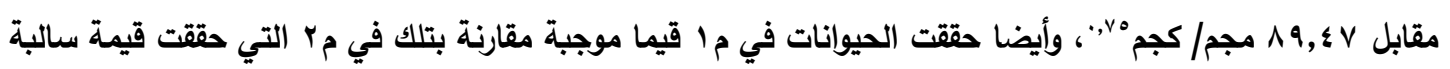

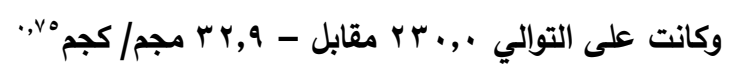

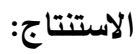

من الممكن استنتاج انه تحت الظروف الصحراوية فإن الأغنام لايها كفاءة خفض إحتياجاتها من طاقة التمثيل الغذائي وخفض الطاقة المفقودة بالدرجة التي تحافظ على وزن الجسم دون تأثر.

$$
\begin{aligned}
& \text { أسماء السادة المحكمين } \\
& \text { أ.د/ بركات محمد أحمد كلية الزراعة - جامعة المنوفية } \\
& \text { أ.د/ رضا سلامه محمد كلية الزراعة - جامعة الأزهر - القاهرة }
\end{aligned}
$$


$\underline{\text { Energy and nitrogen balances as affected by animal species and intake ............... }}$ 
